\title{
Reproductive efficiency of Nellore cows nursing Nellore or crossbred Simmental $\times$ Nellore calves ${ }^{1}$
}

\section{Fernando Miranda de Vargas Junior ${ }^{2}$, Francisco Stefano Wechsler ${ }^{3}$, Marcus Vinicius Morais de Oliveira ${ }^{4}$, Leonardo de Oliveira Seno ${ }^{2}$, Alexandre Rodrigo Mendes Fernandes ${ }^{2}$, Fernando Rossi Camilo²}

\author{
${ }^{1}$ Supported by FAPESP/CAPES \\ ${ }^{2}$ Universidade Federal da Grande Dourados/Faculdade de Ciências Agrárias, Rodovia Dourados - Itahum, km 12, Caixa Postal 533, CEP 79804-970, \\ Dourados/MS, Brazil. \\ ${ }^{3}$ Universidade Estadual Paulista/Faculdade de Medicina Veterinária e Zootecnia - Departamento de Exploração e Produção Animal, Botucatu/SP, \\ Brazil. \\ ${ }^{4}$ Universidade Estadual de Mato Grosso do Sul/Curso de Zootecnia, Aquidauana/MS, Brazil.
}

\begin{abstract}
The objective of this study was to analyze the influence of genetic group (GG) of the calf during gestation, mobilization of body reserves and period of postpartum anestrus in Nellore cows. Thirty-seven primiparous and multiparous cows were used: 24 gave birth to Nellore (NEL), and 13 gave birth to $1 / 2$ Simmental $\times 1 / 2$ Nellore (SIM) calves. According to the date of calving, cows were divided into three blocks, with intervals of 20 days between blocks. The body condition (BC) of the cows was estimated subjectively on a scale from 0 to 5 points, with intermediate grading of 0.5 points. We measured the thickness of subcutaneous fat (SF) between the 12th and 13th ribs and rump by ultrasound. Blood samples from each cow were collected weekly from the third week after birth until weaning, to analyze the level of progesterone; in the samples collected until 16 weeks postpartum, we analyzed the concentration of nonesterified fatty acids (NEFA). The gestation period of mothers of NEL calves was eight days longer, on average. The variables relating to the mobilization of body reserves (NEFA, BC and SF) were not influenced by calf GG, with the only significant effects being the number of days postpartum, with a peak in the concentration of NEFA between the sixth and eighth weeks and linear decrease in BC and NF. Mothers of NEL calves remained in anestrus for 4.6 weeks longer than the mothers of crossbred calves.
\end{abstract}

Key Words: anestrus, body condition, crossing, subcutaneous fat

\section{Introduction}

The conception following parturition is a crucial stage in the cattle raising system, and inefficiency during this phase directly influences the entire production system (Browning Jr. et al., 1996). The interval from parturition to the restart of ovarian activity can be a major obstacle in increasing reproductive efficiency (Williams, 2005), with the postpartum anestrus being largely responsible for long intervals between parturition. This interval is influenced by race, age, nutrition, milk production, breastfeeding or presence of calf, season, and presence of bull (Jolly et al., 1995) and management practices can change its duration.

Several breeds have been used in crosses, with greater emphasis on performance of calves, which becomes apparent when crossing zebus with taurines, producing crossbred calves (Koger, 1980). According to Browning Jr. et al. (1995), the genetic group (GG) of the calf may influence the reproductive performance of cows by changing the length of pregnancy and postpartum return of ovarian activity (Rodrigues, 2009).
The genetic group of the calf influences its performance (Reynolds et al., 1980, 1982; Rodrigues, 2009), but can also affect the reproductive performance of the cow, because it alters the hormonal pre-partum in beef cows (Lammoglia et al., 1995; Browning Jr. et al., 1996).

The crossing of mothers of Indian breeds with bulls of taurine breeds can influence the interval from calving to first estrus and modify the endocrine profile (Browning Jr. et al., 1995, 1996). Browning Jr. et al. (1995) studied the effect of the sire race (Tuli, Angus, Brahman) on the reproductive performance of Brahman cows. The period of anestrus was significantly lower in cows with Brahman calves (82.5 days) than in cows with $1 / 2$ Angus (95.4 days) or Tuli (97.4 days) calves.

Following delivery, there is the onset of competition for energy between the processes of lactation, maintenance and reproduction; the first to be affected in the event of negative energy balance is the reproduction process (Stevenson et al., 1997).

Body condition and weight are the best indicators of energetic nutritional status; they are the determining factors 
in postpartum interval and pregnancy rate, especially in primiparous cows (Bell et al., 1998). The body condition during the breeding season greatly influences ovarian activity and conception rate (Flores al., 2007).

This study was carried out to evaluate the influence of the genetic group of the suckling calf on the duration of gestation, the mobilization of body reserves and the postpartum anestrus in Nellore cows.

\section{Material and Methods}

The experiment was carried out on São Manuel Experimental Farm, which belongs to Universidade Estadual Paulista (UNESP) - Institute of Veterinary Medicine and Animal Science, located in the municipality of São Manuel, state of São Paulo, Brazil. The total grassland area on the farm is 250 ha, divided into 14 paddocks, which kept a stocking rate of $0.9 \mathrm{AU} / \mathrm{ha}$ during the experiment, under continuous grazing alternated according to the available forage. The predominant forage in all paddocks was Brachiaria decumbens.

A total of 37 calving cows (16 primiparous and 21 multiparous) were distributed according to the genetic group (GG) of the calves: 24 Nellore cows with Nellore calves (NEL; 10 primiparous and 21 multiparous); and 13 Nellore cows with $1 / 2$ Simmental $\times 1 / 2$ Nellore calves (SIM; 6 primiparous and 7 multiparous). The method of reproduction was artificial insemination using a bull of each breed, chosen because they were expected to generate a difference in progeny weight gain close to zero.

Calving took place from December 1st, 2001 to January 31 st, 2002. Based on the date of calving, cows were divided into three blocks, with an interval of 20 days between one block and another, distributed as follows: Block A - nine cows (three NEL calves and six SIM calves), block B - 16 cows (14 NEL calves and two SIM calves) and Block C 12 cows (seven NEL calves and five SIM calves).

The gestation period (GP) was calculated as the difference between date of parturition and the last insemination.

The body condition (BC) of the cows was estimated subjectively and independently by three judges at every 14 days after delivery, according to the scale proposed by the Ministry of Agriculture in the UK and described by Radostits \& Blood (1986), ranging from 0 (extremely thin) to 5 (extremely fat), at intervals of half score.

Immediately after the assessment of body condition, the thickness of subcutaneous fat (SF) in the dorso-lumbar region was measured by ultrasonography (Gresham, 1998), between the 12th and 13th rib, and on the back in the region of the biceps femoris muscle. Body condition and ultrasonography were performed independently without communication of results between observers.

Cows were weighed on a mechanical scale with a sensitivity of $1 \mathrm{~kg}$, always after evaluating the $\mathrm{BC}$ and the ultrasound, at every 14 days.

Blood samples from each cow were collected weekly, from the jugular vein, from the third week postpartum until weaning of calves. Two samples of approximately $5 \mathrm{~mL}$ of blood each were collected in vacuum tubes and centrifuged immediately after collection for plasma separation from serum. Serum was stored at $19^{\circ} \mathrm{C}$ for further analysis.

In serum samples collected up to 16 weeks postpartum, we analyzed the concentration of nonesterified fatty acids (NEFA), following the method of Novak (1965).

The postpartum ovarian activity was evaluated daily by observation of estrus in the mornings, with the aid of a bull equipped with a chin-ball mating harness, and by determining the progesterone ( $\mathrm{P} 4)$ levels, from the 21 st day postpartum until weaning.

Progesterone levels were analyzed using a COAT-ACOUNT DPC progesterone solid phase radioimmunoassay kit. We considered the following criteria for establishing the start of the luteal activity: 1) for cows showing estrus and with $\mathrm{P} 4<1 \mathrm{ng} / \mathrm{mL}$ until the moment of observation of estrus, but subsequent peaks $\mathrm{P} 4 \geq 1 \mathrm{ng} / \mathrm{mL}$ we considered the weeks estrus showed; 2) in cows with expression of estrus and $\mathrm{P} 4 \geq 1 \mathrm{ng} / \mathrm{mL}$ just before estrus showed, we considered the week prior to the observation of the $\mathrm{P} 4$ peak; 3) cows with $\mathrm{P} 4<1 \mathrm{ng} / \mathrm{mL}$ until thirty weeks postpartum were considered in anestrus throughout the whole period, regardless of detection of estrus; the latter, when it occurred, was regarded as detection error.

The statistical design was a randomized block with more than a repetition per block. The results for the GP were statistically analyzed by GLM procedure of SAS (Statistical Analysis System, version 6.12), including the fixed effects of block and calf sex and GG in the model, and linear and quadratic effects of the parity order as covariates.

Statistical analysis of the results related to live weight (LW), BC, and NEFA were carried out using the method of restricted maximum likelihood, with the aid of MIXED procedure (Littell et al., 1996) of SAS (version 6.12). The model included effects of block, calf breed and calf sex as fixed the effects in main plots. In repeated measures (trial day), we tested the linear, quadratic and cubic effects of days after parturition, the interactions between them and breed and sex and covariates, order of parturition (linear and quadratic), production of milk and weight. As random effects, we included cow within block, sex and breed (error a) and the residuals (error b). 
Data for SF were analyzed according to a randomized blocks with more than one repetition per block, with repeated measures in space (body region) and time (days postpartum), using the MIXED procedure (Littell et al., 1996) of SAS (version 6.12). Fixed effects of block, GG and calf sex, region of the body (back or rump) and days postpartum were included in the model. Random effects were cow within block, GG and sex (error); the interaction of the region with cow within block, GG and sex (b error); and residuals (c error).

To correlate $\mathrm{BC}$ with SF, we initially fit the $\mathrm{BC}$ model omitting the effect of cows. Next, we set the SF model separately for back and rump, without considering the effects on the cows and body regions. The residuals thus generated were then analyzed using the SAS CORR procedure to obtain the Pearson correlation coefficients for the back and rump.

The results for the period of anestrus (PA) were analyzed using survival curves, with the aid of the PROC LIFETEST procedure of SAS (version 6.12). We tested the effects of blocks, sex and GG of the calf, as well as the linear and quadratic effects of body condition score and order of parity, by means of the Wilcoxon test.

\section{Results and Discussion}

Nellore calves had, on average, eight more days of gestation than the crossbreds (Table 1). This result agrees with those obtained by Koger (1980) and Browning Jr. et al. (1995, 1996), who also observed shorter pregnancies in cows that calved crossbred calves. This effect is possibly due to the larger size and higher birth weight of crossbred calves.

The gestation period can vary (280-290 days) primarily according to the genetic group of cow and calf sex (Rocha et al., 2005). According Baruselli et al. (2007) the duration of pregnancy in Bos indicus (292 days on average) is longer than that of Bos taurus, with an intermediate condition in crossbreds.

Table 1 - Average adjusted lengths of gestation according to calf genetic group and sex

\begin{tabular}{lcccc}
\hline Factor & $\begin{array}{c}\text { Genetic group } \\
\text { or sex }\end{array}$ & Average & Standard error & $\mathrm{P}^{1}$ \\
\hline Calf genetic group & Nellore & 296.7 & 1.24 & 0.001 \\
& $1 / 2$ Simmental & 288.7 & 1.50 & \\
& & & & \\
Calf sex & Male & 293.7 & 1.25 & 0.268 \\
& Female & 291.7 & 1.33 & \\
\hline
\end{tabular}

${ }^{1}$ Probability of type-I error in comparison of means.
We observed linear $(\mathrm{P}=0.0202)$ and quadratic $(\mathrm{P}=0.0382)$ effects of parturition order in GP, which was lower in primiparous females and increased with decreasing speed at higher orders.

There was no effect of the parameters BC, LW, SF, GG, NEFA or calf sex $(P>0.10)$ on any of these variables, apart from the effect of days postpartum. During lactation, there was decrease in BC (Figure 1), a reduction in thickness of both SF and in the back (Figure 3) and an increase in the concentration of NEFA (Figure 4), indicating that, regardless of the measured variable, there was a negative energy balance in the postpartum.

The LW of cows postpartum showed no influence of GG or sex of the calves. Cows showed weight loss from parturition to weaning, with an average LW of $417 \mathrm{~kg}$ during this period (Figure 2).

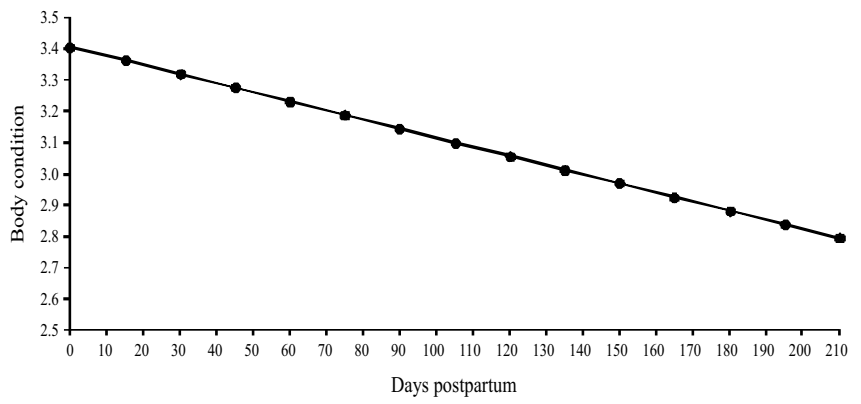

$\mathrm{Y}=2.62-0.00291389$ days

Figure 1 - Body condition of Nellore cows, adjusted according to the number of days postpartum.

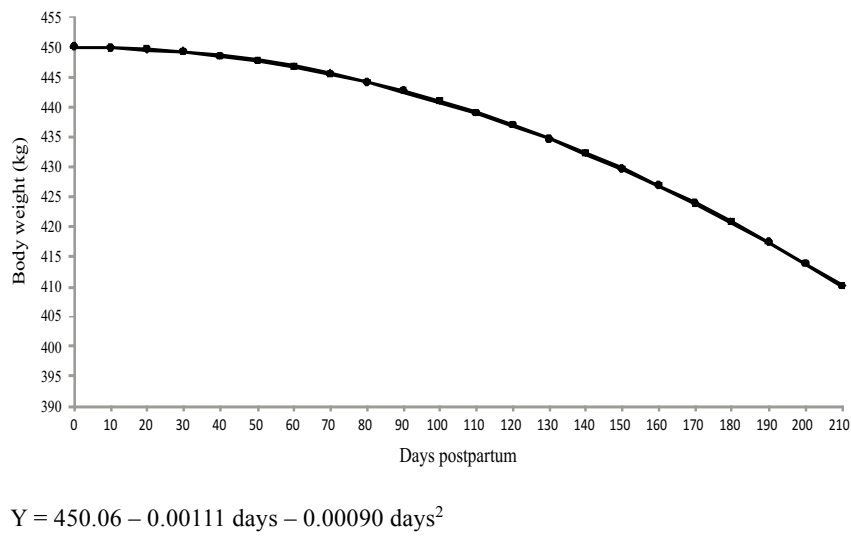

Figure 2 - Body weight of Nellore cows, adjusted according to the number of days postpartum. 
There was a negative energy balance in the postpartum period, as shown by the linear decrease $(\mathrm{P}=0.0001)$ in $\mathrm{BC}$ and quadratic decrease $(\mathrm{P}=0.0010)$ in $\mathrm{LW}$ until weaning. Body condition and LW increased linearly $(\mathrm{P}=0.003$ and $\mathrm{P}=0.0008)$ and quadratically $(\mathrm{P}=0.005$ and $\mathrm{P}=0.0427)$ with the parity order: with increasing order of parturition, cows had higher average $\mathrm{BC}$ and $\mathrm{LW}$, but this effect became progressively weaker as the order of parturition increased.

Females go through the critical period of physiological demand, which takes place during late pregnancy and early lactation. From the eighth to the ninth month of pregnancy, there is a 55\% increase in energy requirement for pregnancy and, from the first to the third month postpartum, the energy required for lactation increases by $40 \%$. If this increased demand for nutrients is not met with the available forage, it will result in negative energy balance, directly affecting reproduction (Meneghetti \& Vasconcelos, 2008).

One should note that the average thickness of the SF was higher in the rump than in the back. There was a linear decrease $(\mathrm{P}=0.0001)$ in thickness, which indicates continuous negative energy balance during the study period. Moreover, there was an interaction $(\mathrm{P}=0.0001)$ between body regions and days after parturition, given that the thickness of the SF decreased more rapidly than in the rump than in the back (Figure 3). There was a correlation between body condition and SF: $0.50(\mathrm{P}=0.0001)$ on the rump and $0.36(\mathrm{P}=0.0001)$ on the back. According to Gresham (1998), rump fat has a higher rate of mobilization than the dorsal fat; thus, if the goal is to check body reserves readily available, the measurement of GS on the back would be the most appropriate procedure.

Schwager-Suter et al. (2000) found a high correlation of $\mathrm{BC}$ with measurements made by ultrasound. The area of measurement of SF thickness by ultrasound that showed

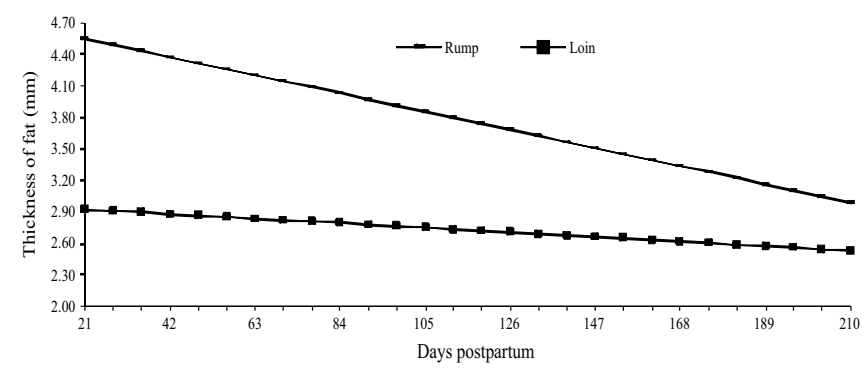

Rump $=4.7232-0.00826$ days

Loin $=2.9683-0.00208$ days

Figure 3 - Thickness of subcutaneous fat, adjusted according to body region and the days after parturition. greatest sensitivity to variations in body condition was the croup, over the loin. These authors state that the BC can be safely used as a substitute for ultrasound.

The concentration of NEFA showed interaction $(\mathrm{P}=0.0696)$ between calf sex and days postpartum, leading to the adjustment of separate regressions. In mothers of females, the concentration of NEFA rose to a peak between the seventh and eighth weeks postpartum; in mothers of males, the peak was reached earlier, around the sixth week. The increase in the concentration of NEFA in this phase indicates the use of body reserves in the energy metabolism of the cow. After six weeks, the gender gap widened, as the mothers of females average NEFA levels remained above $0.7 \mathrm{mM} / \mathrm{L}$ up to 77 days, whereas the mothers of males never reached this level (Figure 4). This effect may be due to greater demand for milk by males, raised by the higher growth rate (Vargas Jr., 2003), which required greater use of cow NEFA readily available in the blood stream, which was not found when the milk production (Vargas Jr., 2003) and body condition of cows were evaluated, causing the difference between the sexes of the calves.

There was a longer period of anestrus $(\mathrm{P}=0.11)$ in cows with NEL calves. Of the 24 cows with NEL calves, $15(62.5 \%)$ were still in anestrus in the 10 th week postpartum, and $9(37.5 \%)$ remained so until the 30th week, when weaning occurred. In the 13 cows with SIM calves, the numbers were, respectively, $4(30.8 \%)$ and 2 (15.4\%) (Figure 5). We also observed a linear effect of $\mathrm{BC}$ $(\mathrm{P}=0.0005)$ and order of parturition $(\mathrm{P}=0.0022)$ on the period of postpartum anestrus.

In cows that give parturition with $\mathrm{BC}=3$, we can expect, on average, 60 days to resume ovarian activity; higher values shorten this period and lower values extend it

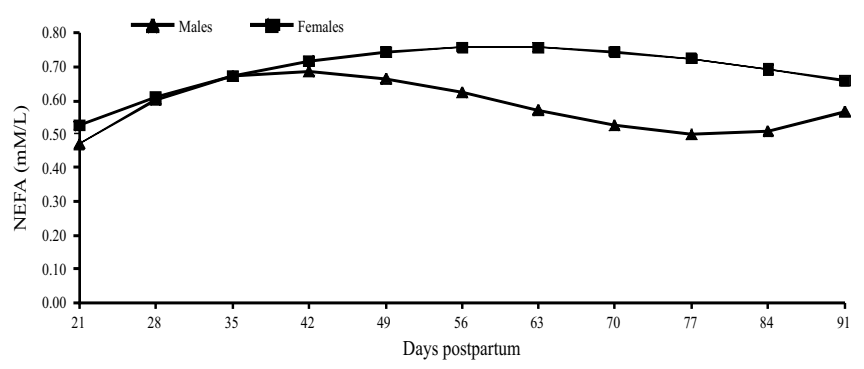

Males $=-45.60+6.726$ days -0.124 days $^{2}+0.0006911$ days $^{3}$ Females $=13.66+2.412$ days -0.028 days $^{2}+0.0000887$ days $^{3}$

Figure 4 - Serum nonesterified fatty acids (NEFA) in cows, adjusted according to days postpartum and calf sex. 
(Lemenager \& Buskirk, 1999). As the estimated BC for the first 60 days was above 3 (Figure 1), we can assume that it was not the limiting factor for resuming ovarian activity. Even taking into account the period between parturition and weaning, the average loss of $\mathrm{BC}$ ( 0.62 points) and $\mathrm{LW}$ $(40 \mathrm{~kg})$ was not as sharp and occurred similarly in mothers of purebred and crossbred calves.

Vargas Jr. (2003) observed higher milk intake by SIM calves, which translates into higher milk production from their mothers, yet increased lipomobilization to compensate for this increased milk production was not detected in the present study. There was a decrease in reproductive performance of Brahman cows as a result of higher demand for milk by the calf (Browning Jr. et al., 1994). This was also observed in Hereford cows by Martins \& Salomoni (1990), who suggested an inverse relationship between the weaning weight of the calf and parturition repetition rate, perhaps because heavier animals require higher milk yield of mothers.

Guédon et al. (1999) observed greater lipomobilization in primiparous cows, and related that to the period for resumption of ovarian activity. This result confirms the effect of parity in DC and during anestrus observed in this study.

According Wettemann et al. (2003), nutrient intake, body energy reserves and breastfeeding are the most important regulators of reproductive performance in beef cows. Inadequate body reserves at calving increase the range of the first estrus and ovulation; postpartum nutrient intake can affect the duration of this interval in cows with low to moderate body condition.

Parturition has low priority in the use of nutrients and tends not to occur if the requirements for maintenance,

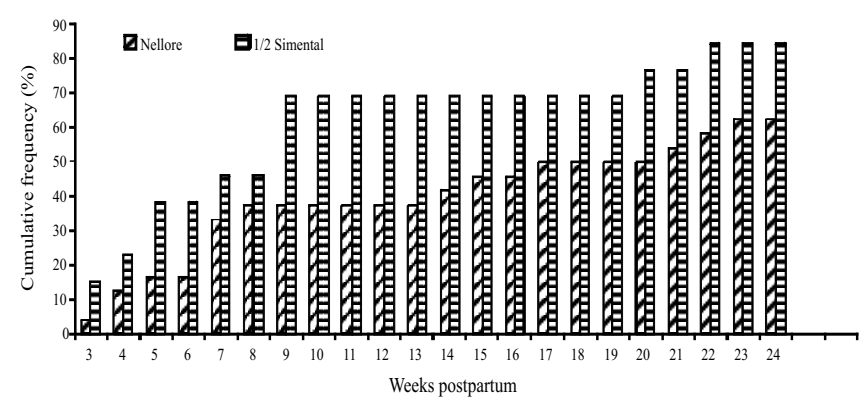

Figure 5 - Cumulative frequency of cows that resumed ovarian activity after calving, grouped by the genetic origin of the calf. growth and lactation are affected; in addition, the resumption of postpartum ovarian activity is inhibited by breastfeeding (Williams, 2005). Breastfeeding, depending on its intensity and duration, prolongs anestrus, influencing it even more than milking (Stevenson et al., 1997). The stimulus of suction is sufficient to inhibit restoration of LH pulses and prolong anestrus; Indian breeds tend to be more affected by both the negative effects of feeding and by deficit in energy than most taurine-breed females (Williams, 2005).

Another important regulator of postpartum ovarian activity and animal behavior is the cow-calf relationship. This consists of several events, where breastfeeding is only one of them. The increased postpartum anestrus is associated with the degree of stimulation of the cow-calf relationship. This is attributed to the increased sensitivity to stimulation of the hypothalamus negative estradiol and endogenous opioids, which suppresses the secretion of GnRH and LH for varying periods (Williams, 2005).

The results of this study suggest that breastfeeding was the most important factor for the resumption of ovarian activity, because: a) there was no difference between genetic groups of calves on the mobilization of body reserves of mothers and b) NEL calves suckled more times per day (Vargas Jr., 2003). This higher frequency of feedings seems to have been the factor responsible for the longest period of anestrus in mothers of NEL calves, indicating a stronger cow-calf relationship.

\section{Conclusions}

The mobilization of body reserves in Nellore cows was not influenced by calf genetic group. Cows maintained a body condition of at least 2.5 to 3.0 ; the main limiting factor is possibly not nutrition, but rather the intensity of the relationship between cow and calf. Thus, mothers of $1 / 2$ Simmental $\times 1 / 2$ Nellore calves showed shorter anestrus, possibly because their resumption of ovarian activity suffers less inhibitory action of sucking.

\section{References}

BARUSELLI, P.S.; GIMENES, L.U.; SALES, J.N. Fisiologia reprodutiva de fêmeas taurinas e zebuínas. Revista Brasileira Reprodução Animal, v.31, n.2, p.205-211, 2007.

BELL, D.J.; SPITZER, J.C.; BURNS, G.L. Comparative effects of early weaning or once-daily suckling on occurrence of postpartum estrus in primiparous beef cows. Theriogenology, v.50, p.707-715, 1998.

BROWNING JR., R.; ROBERT, B.S.; LEWIS, A.W. et al. Effects of postpartum nutrition and once-daily suckling on reproductive efficiency and preweaning calf performance in fall-calving Brahman (Bos indicus) cows. Journal of Animal Science, v.72, p.984-989, 1994. 
BROWNING JR., R.; LEITE-BROWNING, M.L.; NEUENDORFF, D.A. et al. Preweaning growth of Angus - (Bos taurus), Brahman (Bos indicus), and Tuli - (Sanga) sired calves and reproductive performance of their Brahman dams. Journal of Animal Science, v.73, p.2558-2563, 1995.

BROWNING JR., R.; LEITE-BROWNING, M.L.; LEWIS, A.W. et al. Sire breed of calf influences peripartum endocrine profiles and postpartum anestrus in Brahman cows. Domestical Animal Endocrinology, v.13, n.6, p.511-517, 1996.

FLORES, R.; LOOPER, M.L.; RORIE, R.W. et al. Influence of body condition and bovine somatotropin on estrous behavior, reproductive performance, and concentrations of serum somatotropin and plasma fatty acids in postpartum Brahman-influenced cows. Journal of Animal Science, v.85, p.1318-1329, 2007.

GRESHAM, J.D. Real-time ultrasound training conference beef cattle applications. Study guide. Martin, Tennessee: University of Tennessee at Martin, 1998. 24p.

GUÉDON, L.; SAUMANDE, J.; DESBALS, B. Relationships between calf birth weight, prepartum concentrations of plasma energy metabolites and resumption of ovulation postpartum in Limousine sucklend beef cows. Theriogenology, v.52, p.779-789, 1999.

JOLLY, P.D.; McDOUGALL, S.; FITZPATRICK, L.A. et al. Physiological effects of undernutrition on postpartum anoestrus in cows. Journal Reproduction Fertility (Supl.), v.49, p.477-492, 1995.

KOGER, M. Effective crossbreeding systems utilizing zebu cattle. Journal of Animal Science, v.50, p.1215-1220, 1980.

LAMMOGLIA, M.A.; HOLLOWAY, J.W.; LEWIS, A.W. et al. Influence of maternal and service sire breed on serum progesterone and estrogen before calving and plasma 13,14-dihydro-15-ketoprostaglandin F $\alpha$ after calving. Journal of Animal Science, v.73, p.1167-1173, 1995.

LEMENAGER, R.P.; BUSKIRK, D.D. Managing energy reserves to optimize reproduction. In: ANNUAL FLORIDA RUMINANT NUTRITION SYMPOSIUM, 10., 1999, Gainesville, Florida. Proceedings... Gainesville, Florida, 1999. p.33-52.

LITTELL, R.C.; MILLIKEN, G.A.; STROUP, W.W. et al. SAS ${ }^{\circledR}$ System for mixed models. Cary, NC: SAS Institute Inc., 1996. 633p.

MARTINS, C.A.; SALOMONI, F. Efeito do seco e do genótipo da progênie no desempenho reprodutivo subseqüente de vacas Hereford. Revista Brasileira de Reprodução Animal, v.14, n.3, p.187-199, 1990.
MENEGHETTI, M.; VASCONCELOS, J.L.M. Mês de parição, condição corporal e resposta ao protocolo de inseminação artificial em tempo fixo em vacas de corte primíparas. Arquivo Brasileiro de Medicina Veterinária e Zootecnia, v.60, n.4, p.786-793, 2008.

NOVAK, M. Colorimetric ultramicro method for the determination of free fatty acids. Journal of Lipid Research, v.6, p.431-433, 1965.

RADOSTITS, O.M.; BLOOD, D.C. Manual de controle da saúde e produção dos animais. São Paulo: Ed. Manole, 1986. 530p.

REYNOLDS, W.L.; DeROUEN, T.M.; MOIN, S. et al. Factors influencing gestation length, birth weight and calf survival of Angus, Zebu, and Zebu-cross cattle. Journal of Animal Science, v.51, p.860-867, 1980.

REYNOLDS, W.L.; DeROUEN, T.M.; KOONCE, K.L. Preweaning growth rate and weaning traits of Angus, Zebu, and Zebu-cross cattle. Journal of Animal Science, v.54, p.241-247, 1982.

ROCHA, J.C.M.C.; TONHATI, H.; ALENCAR, M.M. et al. Componente de variância para o período de gestação em bovinos de corte. Arquivo Brasileiro de Medicina Veterinária e Zootecnia, v.57, n.6, p.784-791, 2005.

RODRIGUES, W.B. Desempenho e comportamento de vacas Nelores e suas crias puras ou mestiças no Brasil Central. 2009. 73f. Tese (Doutorado em Zootecnia) - Universidade Estadual Paulista, Botucatu.

SCHWAGER-SUTER, R.; STRICKER, C.; ERDIN, D. et al. Relationship between body condition scores and ultrasound measurements of subcutaneous fat and $\mathrm{m}$. longissimus dorsi in dairy cows differing size and type. Animal Science, v.71, p.465-470, 2000.

STEVENSON, J.S.; LAMB, G.C.; HOFFMANN, D.P. et al. Interrelationships of lactation and postpartum anovulation in suckled and milked cows. Livestock Production Science, v.50, p.57-74, 1997.

VARGAS JR., F.M. Efeito do grupo genético da progênie sobre a eficiência produtiva e reprodutiva de matrizes nelores. 2003. 93f. Tese (Doutorado em Zootecnia) - Universidade Estadual Paulista, Botucatu.

WETTEMANN, R.P.; LENTS, C.A.; CICCIOLI, N.H. et al. Nutritional- and suckling-mediated anovulation in beef cows. Journal of Animal Science, v.81, E. Suppl. 2, p.E-48-E59, 2003.

WILLIAMS, G.L. Physiology and management of the postpartum suckled cow for controlled breeding programs. In: WILLIAMS, G.L.; FORREST, D.W. (Eds.) Proceedings, applied reproductive strategies in beef cattle. College Station: Texas A\&M University, 2005. p.184-196. 